\title{
5
}

\section{Competition, ownership diversification and industrial growth}

Mei Wen

The rapid economic development of China, with an average annual GDP growth rate of 9.7 per cent for more than two decades, has been attracting worldwide attention. In particular, among all sectors, China's industry has achieved the highest average annual growth rate of 11.9 per cent from 1978 to 2000 . The fast industrial growth has not only provided Chinese people with abundant manufactured goods and raised living standards, but has also enriched the world market with more variety of commodities at low prices. What makes China's industrial growth so phenomenal?

As market transaction, private ownership and freedom of contracts are the base for an advanced market economy, the transition of a centrally planned economy to a market-oriented economy must experience formation, enlargement and perfection of the market; introduction and strengthening of industrial competition; and ownership diversification or reform of industrial enterprises in the distribution of the rights to claim residual income and control. Since China's economic reform, a market system has been gradually established and continues to improve, industrial competition has been gradually strengthening, and enterprises of diversified ownership types have been emerging and developing.

The market, a basic institution for free trading and free contracting, has to be established gradually in transitional economies. Its size-determined by industrial structure, national purchasing power, transportation and transaction conditionsincreases endogenously with industrial growth. Industrial policies and legal regulations regarding enterprises' behaviour can improve the functioning of the market in 
the provision of information, a level playing field for competition, efficiency of resources and product allocation. Imperfection of the market in transitional economies is a major institutional shortcoming for achieving efficiency, which is easily neglected by economists who take such basic conditions of market economies for granted.

While the market provides a common place for enterprises within an industry to compete with each other, industrial competition increases the market by increasing production, increasing derived demands for factors, improving production efficiency, and therefore increasing industrial GDP. Competition provides incentive mechanisms and additional industrial information for firms to improve their production efficiency. It can either force managers to make more effort to reduce production costs, or drive inefficient firms out of business. It enlarges industrial output with more efficient production, hence improves social surplus. ${ }^{1}$ The efficiency implication of industrial competition is evident in other transitional economies including Mongolia (Carlin et al. 2001; Anderson, Lee and Murrell 2000).

Privatisation has been used as a mechanism to improve firms' internal efficiency since the 1980s in advanced market economies, developing market economies as well as transitional economies. One striking feature of China's transition is the fast industrial growth without large-scale direct privatisation in the first 17 years of reform. But this does not mean that there was no large-scale change in the relative importance of ownership components in industries, and in ownership arrangements within firms. Many studies summarised in Jefferson and Singh (1999) indicate that changes in ownership arrangements within firms and the entry of firms with new ownership types may have made a large contribution to China's rapid industrial growth. In this chapter, the author reviews China's reforms in the light of market competition and ownership diversification, and investigates their contributions to industrial growth.

\section{HOW HAS CHINA ESTABLISHED ITS MARKET SYSTEM?}

China gradually established and developed a market system in three stages. During the first stage, from 1979-84, the Chinese had a 'taste' of the market. During this period, free markets were allowed for trading agricultural products. With the great success of radical agricultural reform-the gradual adoption of the household responsibility system nationwide-markets for agricultural products were activated. Free wholesale and retail markets for small industrial consumption goods were then 
allowed. Gradually, the government reduced the number of industrial products under central planning, raised the procurement prices of agricultural products according to the degree of shortage, adjusted the prices of some light industrial products according to market demand, and let the price of small consumption commodities be determined by the market.

Although establishment of the markets for intermediate goods and primary industrial inputs was not on the reform agenda during this period, due to the necessity for agricultural products and small consumption industrial goods, all Chinese were more or less involved in market transactions. People started to learn how the market works and gain the benefits of the market in product allocation. From purchasing most necessities through quota and queuing at fixed prices, people began to compare different qualities and prices of consumption goods, and learnt to bargain for better quality at a lower price. Although the prices of some necessities increased due to shortages in the early years of economic reform, consumers realised that the market brought them the convenience of purchasing daily necessities, more variety of consumption goods and better-quality products as well as a higher income level.

The second stage was from 1985 to 1991 . This was an important period for ideological change towards a market system. Due to the ideology of socialism that dictated the state ownership of capital goods and land, most intermediate goods, labour, capital and land were still under central planning up to 1985. In 1984, the introduction of the dual-track system-which required output under the plan to be sold at the planned price, while output beyond the plan could be sold at floating prices within a 20 per cent difference of the planned price-allowed state firms in more and more final product industries to transact with non-state marketised firms. In addition, the Central Governmental Decision on the Reform of the Economic System, passed in October 1984 at the third plenary session of the twelfth congress of the Chinese Communist Party, initiated the establishment and development of a market for intermediate goods from 1985-91.

Although high inflation rates during 1988 and 1989 caused suspicion and dispute about the market system, ${ }^{2}$ markets for capital, labour, technology, information and housing were gradually established during this period. Most banks were restructured under state ownership. Workers in SOEs, especially new employees, were shifted to the contract system. Free contracting for the application of most research and development results was allowed. Some departments, such as transportation, 
power, meteorology and banking, started to establish businesses and networks to share information. ${ }^{3}$ With the reform of SOEs towards independent economic entities and the growth of collectives and individuals during this period, the market played a more important role in the economy for the efficient allocation of products and resources.

Comprehensive development for a sound market system occurred in the third stage-from 1992 to the present. Not only were the dual tracks merged to the market prices in 1992 and most intermediate goods opened to market competition, the reform of the housing system towards a semi-commercial system was also executed nationwide. Two stock exchanges were also established in 1992 in Shanghai and Shenzhen. After Deng Xiaoping's southern tour, the fourteenth congress of the Chinese Communist Party, held in October 1992, officially declared that the aim of China's economic reform was to establish a socialist market system.

With the networking of product markets, the introduction of future markets and the adoption of the Internet, a hierarchical network market system was gradually establishing. Adoption of the Internet accelerated development of the product market, while reducing transaction costs and extending the size of the market through e-commerce. It also promoted the development of service markets. The introduction of future markets facilitated inter-temporal optimisation of economic agents.

In 1996, less than 10 per cent of commodity categories were under government control. Over 90 per cent of retail prices and 80 per cent of agricultural and producer good prices (as a proportion of output value) were determined by the market. The number of production factors under central planning fell from 256 in 1979 to less than 20 in 1996. The number of consumption goods under central control declined from 188 in 1978 to 14 in 1996. More importantly, by June 1998, there was no shortage of any of the 610 commodities within state domestic trade statistics. ${ }^{4}$ Shortage had been a common feature of the centrally planned economies (Kornai 1980). After two decades of market-oriented reforms, China eliminated shortages and a buyers' market emerged. However, this does not mean that there are no institutional constraints restricting China's market from functioning more efficiently. In fact, due to the existing household registration system, which limits labour mobility and official interference in banks' lending decisions due to state ownership of most banks, functioning of labour and the capital market is limited, which causes distortions in resource allocation. Although markets for housing and land-use rights exist, they are still immature due to the lack of relevant service agents. 


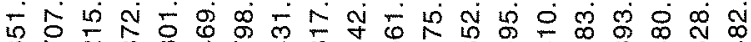
MN N

0 L

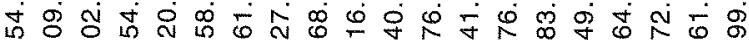

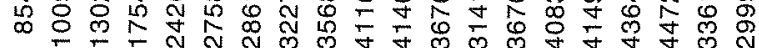

孪

คิ)

以 年 은

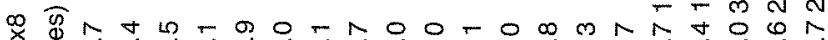

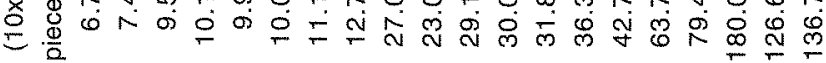

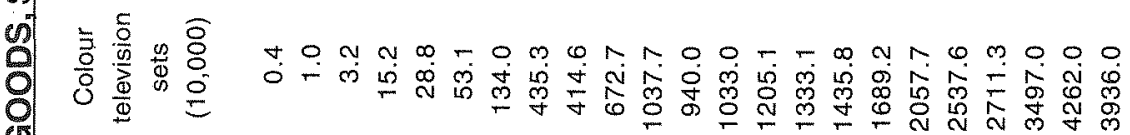

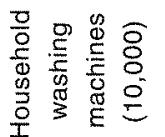

Z

0 N $\stackrel{N}{N}$ in

응

용

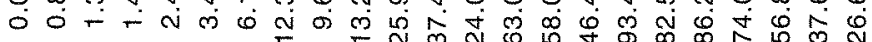

$$
\text { O }
$$

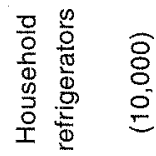

용

$\infty$ \%

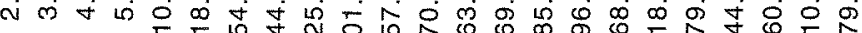

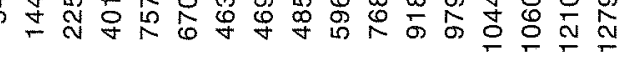

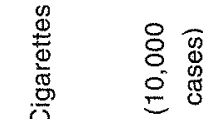

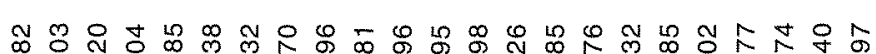

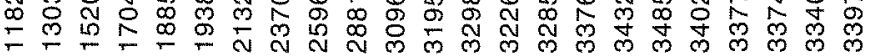
8 क

$\stackrel{\llcorner}{\Phi}$

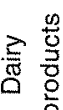
它 응 엉 8
80
0
0
0
0
8
0
0

क人

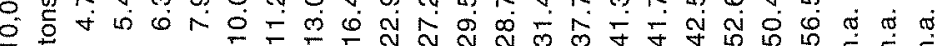

$\stackrel{\circ}{\circ}$ N ठ응 O 
Nevertheless, the development of a market system enabled firms with different ownership types to compete with each other.

During the past two decades, opening up to the world market to increase exports is another means through which China developed its market. With policy encouragement and a firm market-oriented reform environment, the large amount of FDI flowing into China since 1993 has increased China's exports. The endeavour to increase exports has not only made Chinese enterprises participate in rigorous international competition and learn about the market, but also increased the market size tremendously. In 1978, China had net imports of US $\$ 1.14$ billion. Since 1995, however, China's net exports have surged to new levels, reaching US\$24.1 billion in 2000.

\section{INDUSTRIAL COMPETITION AND OWNERSHIP DIVERSIFICATION}

\section{The general trend in industrial competition}

Although the market is far from perfect and relationships (guanxi) still play an important role in conducting business, after two decades of gradual introduction and strengthening of market competition, output has increased for most consumption good industries as shown in Table 5.1. Opportunities emerged from the product shortages and the profits made by enterprises in the early period of reform attracted many entries into various industries. The number of enterprises with the independent accounting systems in each of the 12 industries in Table 5.1 increased from 1978-88. Although the demand contraction policies that began in 1989 drove some small firms out of business, the number of industrial firms continued to increase from 1993-95.

Firms adopted output as a competition strategy in many industries before 1998 due to several reasons. SOEs pursued profits outside state-planning quotas before 1992. On the one hand the central government introduced the policy of a 40 per cent income tax rebate for re-investment from enterprise-retained funds to encourage enterprise investment in fixed assets before 1995. On the other hand, competition among provinces led to severe redundant investment, such that excess production capacity was observed in most industries in the Third National Industrial Census in 1995. Even though the 'excess' market competition drove small enterprises and severe loss-making SOEs out of business, the average size of industrial firms kept 
INDEPENDENT ACCOUNTING SYSTEMS, 1989-1997

Million yuan of net value of fixed assets per enterprise.

\begin{tabular}{|c|c|c|c|c|c|c|c|c|c|}
\hline Industry & 1989 & 1990 & 1991 & 1992 & 1993 & 1994 & 1995 & 1996 & 1997 \\
\hline Food & 0.9 & 1.1 & 1.3 & 1.5 & 1.84 & 2.1 & 2.7 & 3.5 & 4.4 \\
\hline \multicolumn{10}{|l|}{ Beverage } \\
\hline manufacturing & 1.3 & 1.5 & 1.9 & 2.2 & 2.9 & 3.3 & 3.8 & 4.6 & 6.6 \\
\hline Tobacco processing & 19.2 & 25.5 & 33.5 & 41.6 & 45.9 & 50.6 & 64.6 & 105.4 & 108.0 \\
\hline Textiles & 2.7 & 3.2 & 3.8 & 4.4 & 5.2 & 6.0 & 7.2 & 8.9 & 10.5 \\
\hline Garments and other & & & & & & & & & \\
\hline $\begin{array}{l}\text { fibre products } \\
\text { Leather, furs, down }\end{array}$ & 0.4 & 0.5 & 0.6 & 0.9 & 1.2 & 1.5 & 1.7 & 2.1 & 2.7 \\
\hline $\begin{array}{l}\text { and related products } \\
\text { Timber processing, } \\
\text { bamboo, cane, palm } \\
\text { fibre and straw }\end{array}$ & 0.6 & 0.7 & 0.8 & 1.0 & 1.4 & 1.7 & 2.0 & 2.6 & 3.1 \\
\hline $\begin{array}{l}\text { products } \\
\text { Furniture }\end{array}$ & 0.5 & 0.5 & 0.7 & 0.8 & 0.9 & 1.0 & 1.1 & 1.4 & 1.9 \\
\hline $\begin{array}{l}\text { manufacturing } \\
\text { Papermaking and }\end{array}$ & 0.3 & 0.3 & 0.4 & 0.4 & 0.6 & 0.7 & 0.8 & 1.0 & 1.3 \\
\hline $\begin{array}{l}\text { paper products } \\
\text { Printing and record }\end{array}$ & 1.3 & 1.5 & 1.7 & 2.0 & 2.5 & 2.6 & 3.2 & 4.2 & 5.3 \\
\hline $\begin{array}{l}\text { medium reproduction } \\
\text { Cultural, educational }\end{array}$ & 0.6 & 0.7 & 0.8 & 0.9 & 1.2 & 1.3 & 1.5 & 1.9 & 2.2 \\
\hline $\begin{array}{l}\text { and sporting goods } \\
\text { Medical and } \\
\text { pharmaceutical }\end{array}$ & 0.5 & 0.6 & 0.7 & 0.9 & 1.2 & 1.5 & 1.8 & 2.2 & 2.7 \\
\hline products & 2.9 & 3.4 & 4.4 & 5.2 & 5.8 & 6.4 & 6.7 & 8.5 & 10.6 \\
\hline Chemical fibre & 28.9 & 29.5 & 33.2 & 38.8 & 34.1 & 35.7 & 42.1 & 47.7 & 53.7 \\
\hline Rubber products & 1.8 & 1.9 & 2.2 & 2.7 & 3.0 & 3.4 & 4.2 & 5.6 & 7.2 \\
\hline Plastic products & 0.8 & 1.0 & 1.2 & 1.4 & 1.7 & 2.0 & 2.3 & 2.8 & 3.5 \\
\hline $\begin{array}{l}\text { Non-metal mineral } \\
\text { products }\end{array}$ & 1.0 & 1.1 & 1.3 & 1.5 & 1.9 & 2.4 & 2.9 & 3.8 & 4.4 \\
\hline
\end{tabular}

Smelting and

pressing of ferrous

metals

$\begin{array}{lllllllll}20.8 & 23.1 & 26.8 & 31.2 & 25.5 & 24.3 & 29.5 & 39.8 & 48.2\end{array}$

Smelting and

pressing of non-ferrous

metals

$\begin{array}{lllllllll}8.5 & 9.3 & 10.3 & 11.2 & 12.4 & 10.9 & 13.3 & 17.8 & 21.4\end{array}$

Metal products

$0.5 \quad 0.6$

$0.7 \quad 0.8$

$1.1 \quad 1.4$

$\begin{array}{ll}1.8 & 2.2\end{array}$

2.8

Electronic and

telecommunications

equipment

$\begin{array}{llll}3.5 & 3.9 & 5.3 & 6.0\end{array}$

$6.3 \quad 7.3$

$8.6 \quad 10.8 \quad 14.4$

Source: Calculated from State Statistics Bureau of the PRC, 1990-98, Statistical Yearbook of China, China Statistical Publishing House, Beijing. 
increasing (Table 5.2). Although the Asian financial crisis, which started in 1997, caused international markets to weaken and diminished export opportunities, the output of most industrial products has continued to increase while prices decreased consecutively since 1998 . Since then, price games have become common in many industries.

\section{Distinctions among industries}

New entries. Due to the gradual character of China's market formation, the conditions of the market for different products varied during the reform period. The schedule of opening for free trading in the market varied for different products and, hence, the size of different product markets differed at any timepoint during the reform period. In addition, regulations on foreign and domestic private entry, ${ }^{5}$ legal and bank-lending discrimination against domestic private agents, and variations in industrial fixed costs have all meant that the conditions for new entries differed from industry to industry. Subsequently, FDI flowed into each industry, and exports and the strength of competition also varied from industry to industry.

Since the four special economic zones were established in Guangdong and Fujian in 1980, foreign investment has been encouraged in broad manufacturing areas focused on technology introduction and export promotion. Measures adopted to attract FDI include tax redemption and reduction; flexible investment forms such as joint ventures, cooperation, and pure foreign enterprises; gradual extension of open cities and areas; gradual extension of open industries; formal bank-lending policies to joint ventures and foreign enterprises; and legal protection of private properties of foreign agents. Since 1995, these active measures have triggered billions of annual FDI inflow and brought about a technology spillover effect to domestic industry, as well as significantly changing the structure of many industries. For example, after many years of competition, the major players in the automobile industry are all joint ventures. The colour television industry is also dominated by joint ventures. Joint ventures are permitted in most manufacturing industries.

In contrast, domestic private agents were not given enough opportunities to develop large enterprises, making it impossible for them to have their own accumulation of applied research and product development. ${ }^{6}$ Due to the slow accumulation of legalised private property and the lack of formal bank-lending documents supportive of domestic private production investment in the first two decades of the 
reform, the financial constraints were barriers to domestic private entry into high fixed-cost industries. In addition, domestic private economic entities were not given legal support during the early years of the economic reform, until 1996 when the Law of Township and Village Owned Enterprises of the People's Republic of China provided equal legal backing to collective and private TVEs. Furthermore, without the technological advantage that foreign investors brought in, domestic private entry was not encouraged in many industries because of quality and safety concerns. Unfortunately, this seems to have created a vicious cycle: slow legalised private capital accumulation led to low levels of private research and development, low technology led to less opportunities for private agents to enter high-tech areas, less business in high-tech areas led to fewer chances for high capital return, and low capital return led to slow private capital accumulation. Hence, domestic private agents have been facing different barriers to entry than foreigners. Tables 5.3 and 5.4 provide some representative product industries according to fixed costs and barriers to foreign and domestic private entry, respectively, where $x$ of $(x, y)$ stands for fixed costs and $y$ stands for barriers to entry; $H$ is high and $L$ is low. Differences between the entry barriers faced by foreign and domestic private agents can cause the industrial structure to vary substantially from industry to industry.

Unlike private economic entities, however, collective enterprises were legal when economic reform was initiated. This ideological advantage enabled the government to promote the development of industrial collectives, especially industrial township village enterprises, to absorb surplus labour released from the agricultural sector under the institutional constraints of the household registration system and state land ownership in urban areas. ${ }^{7}$ Therefore, the number of industrial township village enterprises increased from 794,000 in 1978 to $7,570,000$ in 1996. Although there

\section{TABLE 5.3 BARRIERSTO FOREIGN ENTRY, (FIXED COSTS)}

(H,H) Representative industries

Tobacco, air-conditioners, mining and processing of Celestine, etc.

(L,H) Representative industries

Colourful light-sensitive material, salt, musk, hand-made carpets, processing of tiger bone, etc. micro-electronic products, small parts for

\section{(H,L) Representative industries}

Civic airplanes; car and motorcycle moulds, textile and paper-making machinery with new technology, etc.

(L,L) Representative industries

Soft drinks, garments, plastic products, new cars, etc. 
was no formal barrier to the entry to collectives in most industries, and bank-lending policies are more favourable to collectives than to domestic private entities, the collectives lack technological and locational advantage compared with most foreign-invested enterprises. Therefore, the difference between the industrial structure of high-tech and low-tech industries in terms of different ownership types (hence exports) depended on the effectiveness of the reform of SOEs.

Ownership diversification. Ownership diversification since the economic reform can be seen in Figures 5.1 and 5.2. In 1978, the three existing ownership types were state ownership, collective ownership and individuals, with collectives and individuals as a whole only having a share less than 0.2 in both investment in fixed assets in the whole economy and in the gross industrial output value. But after more than two decades of market-oriented reform-with a large amount of FDI inflow and the development of industrial collectives-investment in fixed assets through SOEs in the economy dropped to 50 per cent of the total investment in 2000 , while all indus: trial SOEs and state-controlled share companies produced only 28.2 per cent of gross industrial output value.

Although collectives have been the major industrial producers since 1994, their investment in fixed assets was much less than SOEs. Meanwhile, the contribution of individuals and enterprises with other ownership types (mainly foreign and overseas Chinese related) to gross industrial output value has been accelerating. However, the difference between the development of individuals and enterprises of other ownership types lies in the definition of an 'individual'. Individuals are small domestic economic entities that usually have less than eight employees. Hence, they are usually in the retail or service sectors of manufacturing industries. However,

\section{TABLE 5.4 BARRIERSTO DOMESTIC PRIVATE ENTRY,(FIXED COSTS)}

$(\mathrm{H}, \mathrm{H})$ Representative industries

Cars, televisions, telecommunications, spacecraft, power-transmission equipment, nuclear power stations, etc.

(L,H) Representative industries Cigarettes, coal mining, ergot, ergotamine, etc.

\section{$(\mathrm{H}, \mathrm{L})$ Representative industries}

Computers, timber, silk garments, furniture, tyres, etc.

\section{(L,L) Representative industries}

Wool jumpers, garments, food processing, software, small plastic products, wine, CDs, handcraft, kitchen utensils, etc. 


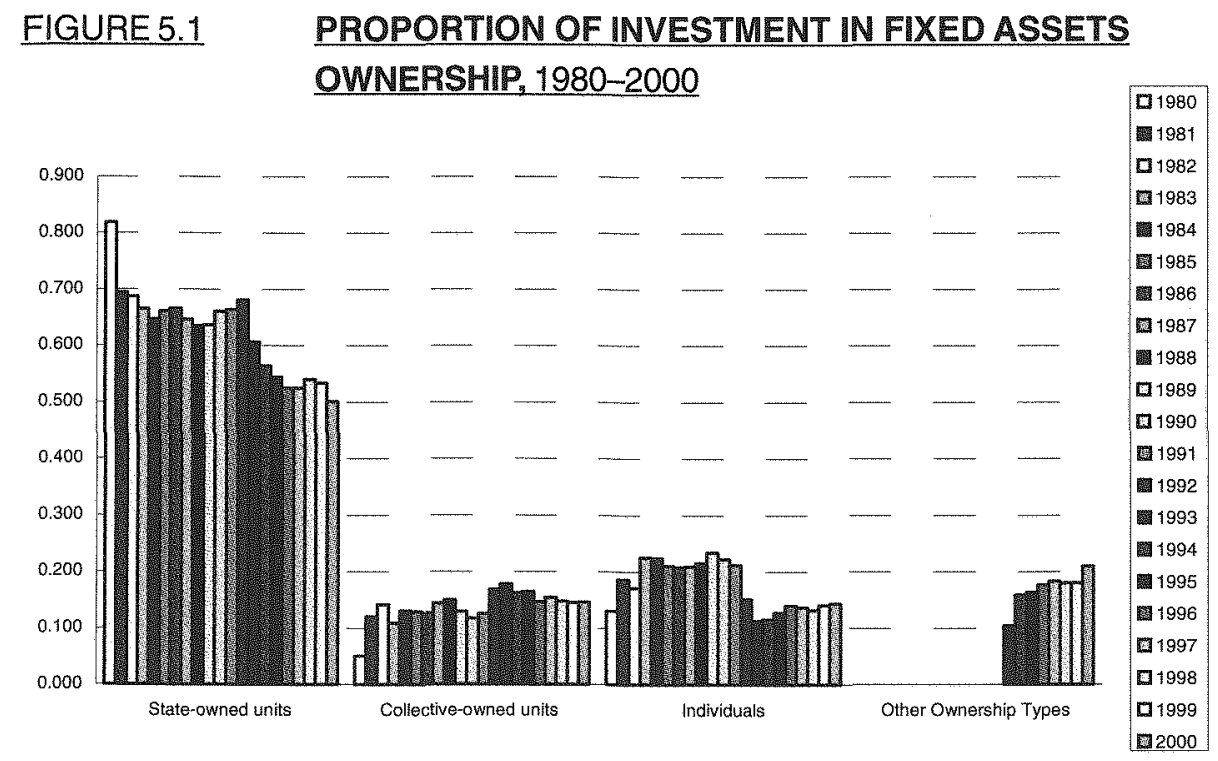

\section{FIGURE 5.2 PROPORTION OF GROSS INDUSTRIAL OUTPUT VALUE BY OWNERSHIP, 1978-1999}

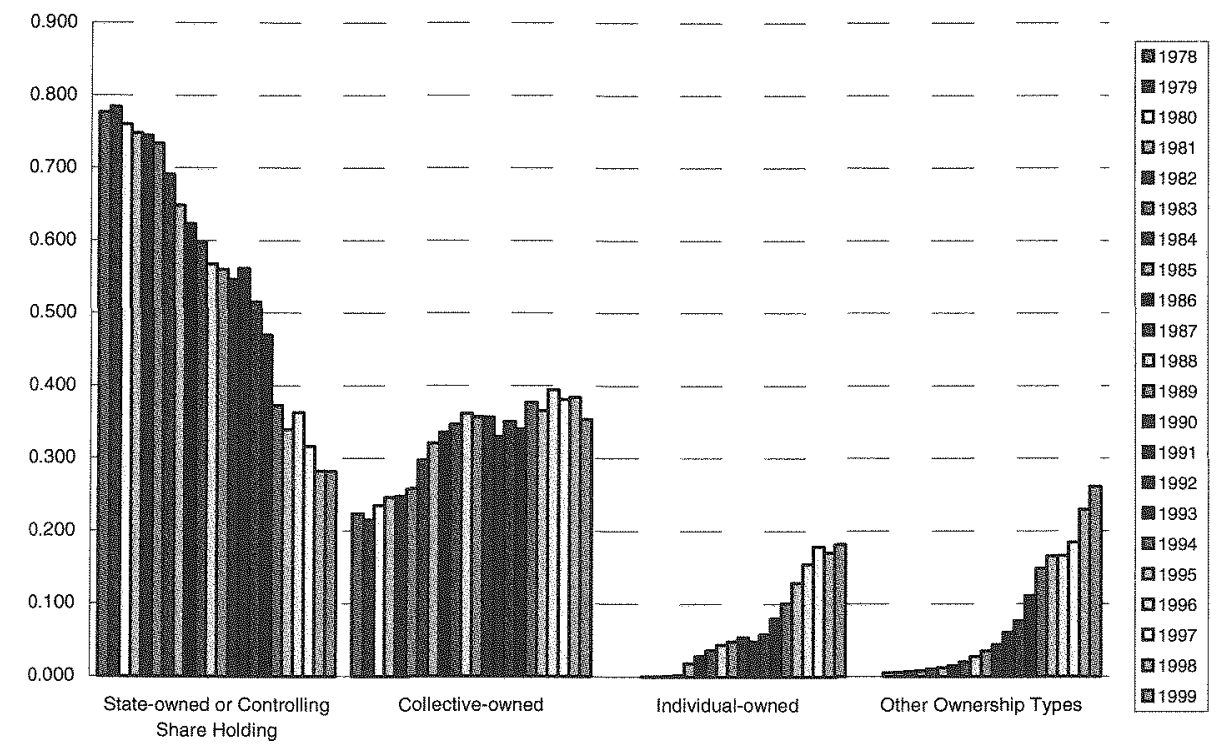


enterprises of other ownership types including many large foreign-funded enterprises were usually found in the production sector. Due to state ownership of most banks and bank-loan policies favouring SOEs (profit-making enterprises are often not strictly distinguished from loss-making ones when banks loan to them), the financial disadvantage of collectives and domestic private agents can make them weaker in current and future industrial competition. In these circumstances, China's accession to the World Trade Organization will further change the ownership structure of many industries towards a larger foreign-funded sector.

Competition in different industries. This analysis is limited to two-digit industries, as data on product market are not available. Fixed costs, number of firms and the strength of competition varied from industry to industry. For example, there were 82 enterprises above the designated size in the petroleum and natural gas-extraction industry and 14,540 in the non-metal mineral products industry in $2000 .{ }^{8}$ Generally speaking, there is strong competition in most manufacturing industries, while competition in extraction industries is mainly oligopolistic. Within manufacturing industries, only the competition in the tobacco industry is restricted mainly among SOEs. In the other manufacturing industries, major players include collectives and foreign-funded enterprises.

Although the percentage of foreign-funded enterprises was very small in the six extraction industries and the gas, water and power-supply industries, foreign-funded enterprises occupied a large share (among all enterprises above the designated size) in some manufacturing industries such as 0.72 in the gross industrial output value of the electronic and telecommunications equipment industry, 0.57 in the instruments, meters, and office-machinery industry, 0.60 in the cultural, educational and sports-goods industry, 0.56 in the leather, furs, down and related products industry and 0.49 in the garments and other fibre products industry in $2000 .^{9}$

More importantly, according to the Statistical Yearbook of China 2001, the average size of foreign-funded firms (in terms of annual average balance of net value of fixed assets per firm) is bigger than the average size of all enterprises above the designated size in 23 out of the 28 manufacturing industries. Only in the chemical fibre industry and three industries that have higher fixed costs and few foreign entries (the share of the foreign-funded sector is less than 10 per cent), the average size of foreign-funded firms is smaller than the average size of all enterprises above the designated size.

Quantity games were common in consumption-good industries in the earlier years 
of the economic reform. But in the 1990s, with FDI inflow and the development of joint ventures, price games started in many household electrical items such as television sets, fridges and air-conditioners. Since there was excess production capacity in many industries in 1995, price games were common in industries with severe excess capacity. Due to the SOEs' soft budget problem and a lack of effective exit for insolvent SOEs, competition from big foreign-funded enterprises drove SOEs to make more losses. As foreign-funded enterprises usually had advanced technology, better management and easy access to licences for exports in industries where there was export licence management, the foreign-funded sector occupied an even larger share in sales revenue and total profits. But due to policies favourable to foreign direct investment through tax exemption or reduction, the total tax payable by the foreign-funded sector was less than by the domestic sector. The larger firm size in the foreign-funded sector, the further release of restrictions on foreign direct investment after China's WTO accession, and taxation policy changes towards foreign-funded enterprises will affect major players in many industries in the near future. There could also be capacity games for entry deterrence against domestic private agents.

\section{Efficiency implications of industrial competition and ownership diversification}

It is believed that private ownership can make firms more efficient than state ownership due to clearly defined property rights, hence lower agency costs, when information and contracts are incomplete and transaction costs are not negligible. Hence, privatisation will improve production efficiency and social surplus in industries not benefiting from economies of scale. Although China has never had large-scale privatisation, reforms within SOEs gave managers more control and more rights to claim residual income. As studies comparing technical efficiency among enterprises of different ownership types in China's economy have found that SOEs are less internally efficient than enterprises of other ownership types on average, the introduction and development of a variety of ownership types in the economy must have improved efficiency (see Zhang, Zhang and Zhao 2001; Wen, Li and Lloyd forthcoming).

Competition makes firms run more efficiently through both the incentive effect and the information effect. Increases in the number of firms and industrial output force managers to put more effort into cost reduction for achieving the same amount 
of profit. Although this effect may not be strong for firms facing a soft budget, competition makes firms' inefficiency apparent as they make losses. This can provide the government with information about the ability of SOEs' managers, or about managers' attempts to improve internal efficiency. For example, in 1996, the Chinese government observed the successful performance of Handan Steel Company and made it a well-managed and cost-cutting model for other SOEs to emulate. Although examples such as the Handan Steel Company are a very small fraction of SOEs and many loss-making SOEs can still get bank loans, market competition drives relatively inefficient firms with the same ownership types in the non-state sector out of business. Furthermore, competition squeezes the costprice margin and forces firms to have stronger incentives to develop new products and explore new markets. Therefore, gradually strengthened industrial competition, introduction of more efficient ownership types and development towards more flexible ownership types in China's industry may have improved industrial efficiency.

The exact extent to which competition and ownership diversification can improve industrial efficiency is unknown, especially in transition economies. Some economists argue that transfer of ownership is more important for efficiency gain in transitional economies while others claim competition is essential. Hence, further quantitative research is required.

\section{CONTRIBUTION OF COMPETITION AND OWNERSHIP DIVER- SIFICATION TO INDUSTRIAL GROWTH}

Measurement of the strength of industrial competition is a very difficult task, especially in transitional economies where the market is not perfect. Historical statistics for rough ownership classification exist in China. As many statistics before 1998 used state ownership, collective ownership, individuals and the other ownership types as the four big categories of ownership groups, this classification is adopted to study the effect of ownership diversification on industrial total factor productivity. As the sum of the shares across all ownership groups is a constant ${ }^{10}$-and individuals are relatively less important in the industrial production sector, the shares of SOEs-collectives and enterprises of other ownership types in the gross industrial output value will be used as explanatory variables in the following regression of the production function. 
Due to limited data availability, this chapter evaluates the contribution at an industry level only (as a subsection of a secondary industry parallel with the construction industry). As the number of firms within a product industry can approximately reflect the degree of industrial competition, ${ }^{11}$ and the development of substitutes usually increases the total number of industrial firms as new product, industry may emerge. The number of industrial enterprises will be used to approximately measure the effect of competition on total factor productivity.

Annual data from 1978-97 are used to evaluate the competition and ownership effects. After trying both the translog and the Cobb-Douglas production functions, it is found that the Cobb-Douglas production function provides a better fit of the data (see Table 5.5).

In the regression, the number of industrial firms, the share of collectives and the share of enterprises with other ownership types are significant at the 0.05 level while capital, which is roughly measured by the annual balance of the net value of fixed assets, is significant at the 0.01 level (Table 5.5). Labour input (total number of employees) and share of SOEs are not significant even at the 0.50 level.

The insignificance of labour input is not surprising as both SOEs and collectives have been overstaffed. The share of SOEs is not significant, indicating that the disembodied improvement of total factor productivity in the state sector is negligible. However, there is significant disembodied technology improvement in the collective sector and the other ownership types sector. Furthermore, the total factor productivity of enterprises with other ownership types is higher than collectives.

Although the majority of studies found that the reforms of SOEs did improve the internal efficiency of SOEs (Jefferson and Singh 1999), efficiency improvement may be mainly through investment in fixed assets. According to the regression, competition and capital inputs significantly contribute to industrial growth.

From the regression and the historical data, approximately 10 per cent of average annual industrial growth is due to disembodied total factor productivity improvement from ownership diversification. On the effect of competition, this regression only reveals its significance. Its extent cannot be calculated because the contribution of competition to industrial growth still seems to be mainly through increased inputs. The cost-reduction effect can be partly offset by inefficient allocation of resources among different ownership groups at an aggregate level. 

LN OF INDUSTRIAL VALUE ADDED)

Explanatory variables

Intercept

LnL

LnK

Number of industrial enterprises

Share of state-owned enterprises in gross

industrial output value

Share of collectives

Share of enterprises with other ownership types

Adjusted $\mathrm{R}^{2}$

$\begin{array}{cc}\text { Estimated coefficients } & \text { P-value } \\ 1.056 & 0.543 \\ 0.038 & 0.867 \\ 0.685 & 4.93 \mathrm{E}-06 \\ 1.36-\mathrm{E} 04 & 0.043 \\ & \\ 0.310 & 0.671 \\ 2.022 & 0.030 \\ 3.967 & 0.017 \\ 0.999 & \end{array}$

This regression is the first trial of the quantitive evaluation. To get a more accurate evaluation of the contribution of competition and ownership diversification to industrial performance, product industry-specific studies are needed. Better measures for competition are required. Endogeneity of ownership shares should be considered as well.

\section{CONCLUSION}

During China's two-decades of economic reform, a hierarchical and networking market system has been forming. Although the market can yet be improved, competition based on the market mechanism has significantly contributed to China's industrial growth. Even though there was no large-scale privatisation of SOEs, the introduction and development of enterprises with diversified ownership types has increased industrial total factor productivity due to more clearly defined property rights within these enterprises. A primary estimate is that about 10 per cent of the average annual industrial growth comes purely from ownership diversification excluding embodied technology changes.

China's accession to the WTO is bringing in more FDI and stronger international competition. How the industrial structure will evolve depends not only on past government policies and regulations toward enterprises with different ownerships types, and the present ownership structure in different industries and industrial character, but also on the differentials in production efficiency of enterprises with different ownership types, the financial and liquidity constraints different enterprises face, and future industrial policies and regulations. Although various industries will face 
different challenges, improving the efficiency of the domestic industrial sector is crucial for domestic firms. As the cost reduction effect of market competition can be partly offset by misallocation of resources among different ownership sectors at aggregate level. To enhance the efficiency of the domestic industrial sector, further development of collectives and domestic private enterprises is desirable, together with the ownership transformation of SOEs.

Measures to improve market conditions and allow competition to exert its full function, such as equal treatment of enterprises with different ownership types in bank loans, more effective exits for insolvent firms and further development of the market system including the development of markets for secondary assets, may bring more efficiency gains.

\section{Notes}

1 In the case where insolvent firms face a soft budget, and increase in output is from lossmaking firms, social surplus can decrease.

2 The general consumer price index was 18.8 per cent and 18.0 per cent in 1988 and 1989, respectively.

${ }^{3}$ A typical example of the establishing information market in the 1980s was the increase in small businesses that collect and provide information on the route of empty trucks and the demand for trucks for road commodity transportation.

${ }_{4}$ Data provided in this paragraph are from the Editorial Office of China Economic System Reform Yearbook, Yearbook of China's Economic System Reform 1999.

5 Refer to the 'Guiding list of industries for investment by foreign businessmen' (issued on 20 June 1995 by the Ministry of Foreign Trade and Economic Cooperation, amended in December 1997) in the Gazette of the State Council of the People's Republic of China 1997 (40) for past regulations on foreign entry into China's industries. The legal documentation for World Trade Organization accession signed by China can be considered as the new regulations. There were restrictions in dometic private entry into industries which use very scarce resources; which are vital to national economy; or whose products are certain public hazards. See Garnaut et al. (2001) for some sample industries in which domestic private entry was limited.

${ }^{6}$ A very recent survey reveals that some domestic private enterprises have used $R$ and D to win market compatition (see Garnaut et al. 2001), such examples are not common in the economy.

7 See Wen and Zhang (2001) for the contribution of township village enterprises in $a b^{-}$ 
sorbing surplus labour and in gross industrial output value.

${ }^{8}$ The designated size of enterprise refers to annual sales of five million yuan.

9 Data are calculated from Statistical Yearbook of China 2001.

${ }^{10}$ The better measures can be the industrial-concentration ratio and the Herfindahl index although they are not perfect measures when firms are not profit-maximisers or when there is a large proportion of transactions outside the market.

${ }^{11}$ Statistics by ownership group provided in Statistical Yearbook of China and Industrial Statistical Yearbook of China after 1997 changed the classification of ownership groups, hence consistent data for 1998, 1999 and 2000 are not available. 